\title{
The international mobility of UK students; a government funded initiative
}

\author{
Keith McCormick ${ }^{1 *}$, Cathy Bowen ${ }^{1}$, Jasper Tong ${ }^{2}$, Mike Potter ${ }^{1}$ \\ From Society of Chiropodists and Podiatrists Annual Conference 2010 \\ Bournemouth, UK. 21-23 October 2010
}

\section{Introduction}

The British Council Connect initiative was set up to support strategic alliances and partnerships, promoting student learning overseas. With suitable training, risk analysis and agreements in place, this gave us the potential to explore off shore practice based learning, clinical attachments.

\section{Method}

A successful grant application was made to the British Council as part of the Prime Minister's Initiative for International Education (PMI2). A remote clinical educators network was identified, and training delivered. Five, third year students spent a month 'hands on' placement in five different hospitals in Singapore. Qualitative and quantitative data was collected from educators and students.

\section{Results}

16 applicants competed for five places. All students passed their clinical attachment without incident, Overall mean rating for the placement; 5 out of $5(1=$ poor and $5=$ excellent). Mean student score for the value of 'clinical activities'; 4.8. Overall mean student score for all 14 criteria; 4.51. Accommodation, induction and preparation for the placement; although satisfactory, were identified as areas for improvement.

\section{Discussion}

This is the first UK podiatry initiative providing undergraduate students with hands on credit bearing clinical attachments overseas. Repeat funding is being sought. Students benefited greatly from high quality clinical education and the cultural experience.

University of Southampton, Hampshire, UK,
Author details

${ }^{1}$ University of Southampton, Hampshire, UK,. ${ }^{2}$ Singapore General Hospital, Sing Health Group, Singapore.

Published: 20 December 2010

doi:10.1186/1757-1146-3-S1-016

Cite this article as: McCormick et al.: The international mobility of UK students; a government funded initiative. Journal of Foot and Ankle Research 2010 3(Suppl 1):016.
Submit your next manuscript to BioMed Central and take full advantage of:

- Convenient online submission

- Thorough peer review

- No space constraints or color figure charges

- Immediate publication on acceptance

- Inclusion in PubMed, CAS, Scopus and Google Scholar

- Research which is freely available for redistribution
() Biomed Central
Full list of author information is available at the end of the article

C Biomed Central 